\title{
Fissidentalium badense (PARTSCH in HÖRNES, 1856) from the Badenian deposits of the south and southwestern margin of the Pannonian Basin System (Central Paratethys)
}

\author{
Gordana Jovanović ${ }^{1}$ and Marija Bošnjak ${ }^{2}$ \\ ${ }^{1}$ Natural History Museum Belgrade, Department of Paleontology, Division of Geology, Njegoševa 51, Belgrade, Serbia; (gordana.j@nhmbeo.rs) \\ ${ }^{2}$ Croatian Natural History Museum, Department of Geology and Paleontology, Demetrova 1, Zagreb, Croatia; (corresponding author: marija.bosnjak@hpm.hr)
}

doi: $10.4154 / g c .2016 .20$

Crossref

Article history:

Manuscript received December 16, 2015 Revised manuscript accepted May 31, 2016 Available online June 28, 2016

Keywords: Fissidentalium badense, Badenian, Pannonian Basin System, Central Paratethys

\begin{abstract}
The Badenian (Middle Miocene) Scaphopoda from the south and southwestern margin of the Pannonian Basin System (Central Paratethys) are poorly documented, and in published papers mostly presented by short lists of identified species. For the present study, 300 scaphopod specimens were examined with the focus on a singular species, Fissidentalium badense (PARTSCH in HÖRNES, 1856). This species is represented by 152 specimens housed in the Natural History Museum Belgrade and the Croatian Natural History Museum in Zagreb. The most numerous and the best preserved specimens of $F$. badense were collected at the Višnjica locality near Belgrade (Serbia), while the others originate from the vicinity of Zagreb (Croatia) and Ugljevik (Bosnia and Herzegovina).
\end{abstract}

\section{INTRODUCTION}

The Scaphopoda is a class of Mollusca, also known as the "tusk shells". Their shell is tubular and generally curved, having openings at both ends. Scaphopods are a cosmopolitan marine infaunal species, and live from the intertidal zones down to depths of more than $6000 \mathrm{~m}$. Scaphopod species mostly burrow in sand or mud, with their head pointed downwards, and the narrow posterior end of the shell protruding above the substratum (KNUDSEN, 1964; LAMPRELL \& HEALY, 1998 and references therein; HABDIJA et al., 2011).

Although the scaphopod systematics have been revised over a few decades, the time of their appearance is still a matter of debate, as are their phylogenetics, so they are considered to be a puzzling molluscan class. Two orders of scaphopods are known: Dentaliida and Gadilida, which differ both morphologically, in shell and foot form, and behaviourally, in different burrowing activities (LAMPRELL \& HEALY, 1998 and references therein; STEINER \& KABAT, 2001, 2004).

This paper focuses on the Badenian dentaliid species Fissidentalium badense (PARTSCH in HÖRNES), recorded in the Miocene deposits of the Paratethys, and widely distributed in Badenian sediments of the Central Paratethys (e.g. BALDI, 1960; KOJUMDGIEVA \& STRACHIMIROV, 1960; BALLUK, 1972; TITA, 2007; HARZHAUSER et al., 2011). Specimens of $F$. $b a$ dense included here were collected from the Badenian sediments of the south and southwestern margin of the Central Paratethys (Croatia, Bosnia and Herzegovina and Serbia). The analyzed specimens are housed at the Natural History Museum Belgrade (NHMB) and Croatian Natural History Museum (CNHM). The first finding of $F$. badense from Bosnia and Herzegovina is published here.

\section{GEOLOGICAL SETTING}

The Central Paratethys extended from Bavaria to the Carpathian mountain chain (e.g. RÖGL 1998, 1999). Badenian sediments from the investigated area belong palaeogeographically to the south and southwestern margin of the Central Paratethys, and geotectonically to the Pannonian Basin System, surrounded by the Alps, Carpathians and Dinarides (Fig. 1) (e.g. RÖGL 1998, 1999; PAVELIĆ, 2001, 2002; PILLER et al., 2007).

The beginning of the Badenian epoch is marked by a marine transgression, which flooded the areas behind the newly uplifted mountain chains (Paratethys) and was also prominent in the Mediterranean (Fig. 1) (RÖGL, 1998, 1999; KOVÁČ et al., 2007). According to numerous papers, the Badenian deposits of the south and southwestern margin of the Central Paratethys lie discordantly on the older Miocene, Mesozoic or even Palaeozoic deposits. The contact with basal rocks is in many places unclear or erosive or tectonic in character (e.g. ŠIKIĆ et al., 1978, 1979; BASCH, 1983a, b; VRABAC \& MIHAJLOVIĆ, 1990; ANĐELKOVIĆ et al., 1991; PAVELIĆ, 2001, 2002; SAVIĆ et al., 2005; PIKIJA, 2009).

At the southern margin of Central Paratethys, F. badense is recorded in the Lower Badenian deposits of Serbia (wider Belgrade region) (PETKOVIĆ et al., 1976), in the assumed Lower to Middle Badenian of western Serbia (ŽUJOVIĆ, 1889; PAVLOVIĆ, 1903; STEVANOVIĆ, 1949; PETROVIĆ, 1967), and in the Lower Badenian (Upper Lagenidae zone) in northeastern Bosnia and Herzegovina (Bogutovo Selo) (VRABAC et al., 2013, 2014; PEZELJ et al., 2013) (Fig. 1). In the area of the southwestern margin of the Central Paratethys, this species is present in the Miocene (probably Lower Badenian) marls of the wider Zagreb region (Medvednica Mt., Čučerje area) (KOCHANSKY, 1944, 1957; ĆORIĆ et al., 2009), and in the assumed Middle to Upper Badenian deposits of the Samobor area (Vrhovčak locality, previously known as „Zaprešić Breg“ or „Zaprešić brijeg“) (ŠUKLJE, 1929; PAVLOVSKY, 1957, 1960; BAJRAKTAREVIĆ, 1978; VRSALJKO, 2003; BAKRAČ et al., 2010). In the Badenian sediments of the Glinsko Pokuplje area, this species is found at one locality (PILAR, 1873). 


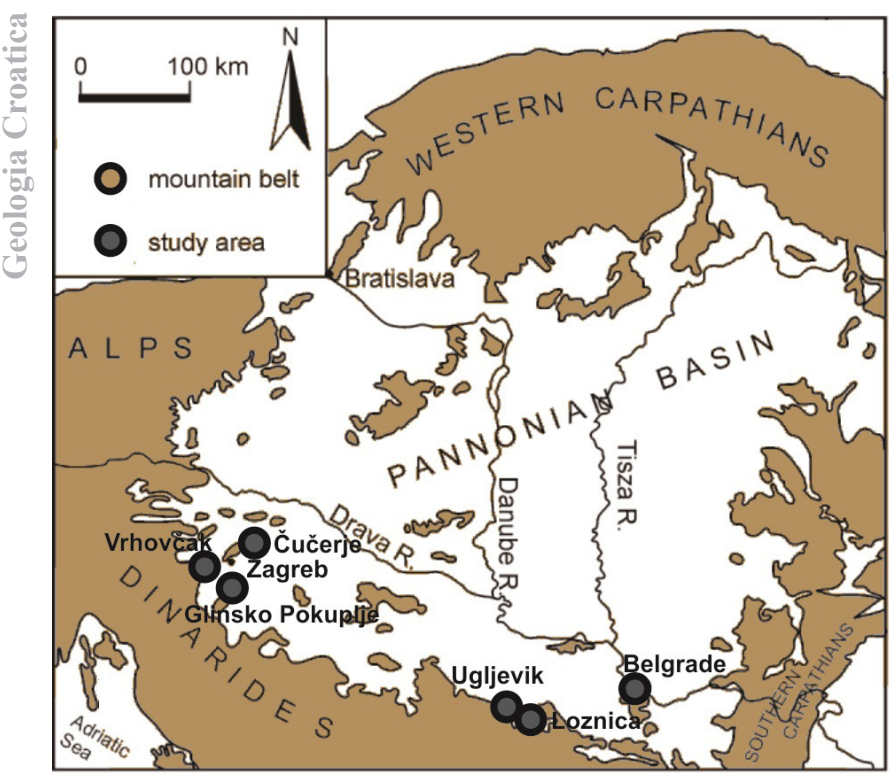

Figure 1. Geographic and paleogeographic setting of the investigated area with marked localities containing recorded dentaliids (after KOVÁČ et al., 2007).

\section{MATERIALS AND METHODS}

Three hundred scaphopod shells were examined, and 152 of them belong to the species Fissidentalium badense (PARTSCH in HÖRNES). All the analyzed specimens are damaged, mostly in the apex area, and the majority of specimens are preserved as shell fragments.

NHMB specimens were collected at the Višnjica locality (wider area of Belgrade), and they are a part of the P. Pavlović collection, assembled in 1897 (90 specimens) and the P. Stevanović collection, assembled in 1962 (40 specimens). Other specimens come from the Loznica area in western Serbia (3 specimens), and Bogutovo Selo near Ugljevik, Bosnia and Herzegovina (1 specimen).

CNHM specimens originating from the wider Zagreb region are part of the „Marine Miocene fauna of the southern part of the Medvednica Mt.“ collection (10 specimens) and the „Miocene fauna of Zaprešić Breg near Samobor" collection (5 specimens). Specimens from the third locality are part of the „Miocene and Pliocene fauna from the Glinsko Pokuplje area and ZrinjskoDvorska valley“ collection (3 specimens).

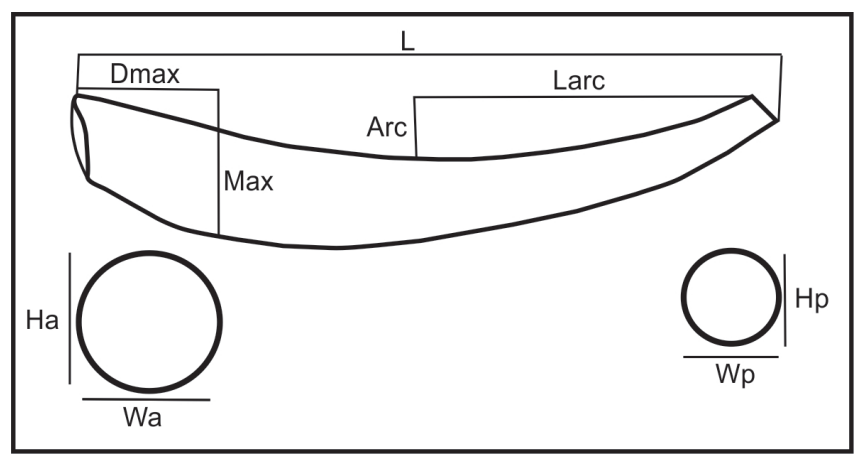

Figure 2. Morphometric measurement parameters: $\mathrm{L}$ - length, Max - maximum diameter, Dmax - maximum distance from the anterior opening, Arc - curvature maximum, Larc - maximum length from the apex to the deepest point of the curvature, $\mathrm{Ha}$ - height of the ventral opening, $\mathrm{Wa}$ - width of the ventral opening, $\mathrm{Hp}$ - apical height, Wp - apical width (after STEINER, 1999; SILVA-FILHO et al., 2012).
The site yielding the largest number of scaphopods is Višnjica (Fig. 1), with 280 specimens from clayey sediments, 130 among them belonging to $F$. badense (LUKOVIĆ, 1922; JOVANOVIĆ \& JOVANOVIĆ, 1998). This fossil fauna is the best preserved, and therefore chosen to be described here.

Determination of species is based upon several papers (e.g. HÖRNES, 1856; SACCO, 1897; KOJUMDGIEVA \& STRACHIMIROV, 1960; PAVIA, 1991; STEINER \& KABAT 2001, 2004). Parameters used in the determination are after STEINER (1999) and SILVA-FILHO et al. (2012) (Fig. 2).

\section{RESULTS}

\section{SYSTEMATIC PART}

Class Scaphopoda Bronn, 1862

Order Dentaliida da Costa, 1776

Family Dentaliidae Children, 1834

Genus Fissidentalium Fischer, 1885

Subgenus Antalis Adams \& Adams, 1854

Fissidentalium badense (Partsch in Hörnes, 1856)

(Pl. 1, Figs. 1-6)

Type species: Dentalium ergasticim FISCHER, 1885, monotype 1856 Dentalium Badense - HÖRNES, p. 652, pl. 50, fig. 30

1897 Entalis badensis (PARTSCH) et var. - SACCO, p. 107-108, pl. 9, figs. 17-30

1925 Dentalium (Entalis) badense PARTSCH var. borealis

KAUTSKY - KAUTSKY, p. 53-54, pl. 5, fig. 12

1929 Dentalium badense (PARTSCH) - ŠUKLJE, p. 52

1947 Dentalium (Fissidentalium) badense PARTSCH - TAU-

BER, p. 302, pl. 7, figs. 8-10, pl. 8, fig. 3

1897 Entalis badensis - SACCO, p.107, pl. 9, figs. 17-20

1960 Dentalium (Entalis) badensis PARTSCH in HÖRNES -

KOJUMDGIEVA \& STRACHIMIROV, p. 225, pl. 52, figs. 19-20

1960 Dentalium badense PARTSCH - BALDI, p. 57, pl. 1, fig. 5

1991 Fissidentalium badense (PARTSCH in HÖRNES, 1856) -

PAVIA, p. 146, pl. 5, fig. 4; pl. 6, fig. 6. (cum syn.).

1998 Dentalium badense PARTSCHI - JOVANOVIĆ \& JOVANOVIĆ, p. 201-202

2011 Fissidentalium badense (PARTSCH in HÖRNES, 1856) HARZHAUSER et al., p. 219, pl. 8. figs. 6-7

2013 Dentalium (Antalis) badense (PARTSCH, 1856) - ROUTNEROVÁ, p. 20, pl. 2, fig. 2

Material: 20 relatively well preserved and 110 damaged specimens from the Višnjica locality, 3 specimens from the Loznica area (Serbia), 10 damaged specimens from the Medvednica Mt. (Čučerje area), 5 specimens from the „Zaprešić Breg“ locality and 3 specimens from the Glinsko Pokuplje area (Croatia), 1 specimen from Bogutovo Selo near Ugljevik (Bosnia and Herzegovina).

Dimensions: $\mathrm{L}=37.3 \mathrm{~mm}$; $\operatorname{Larc}=32.0 \mathrm{~mm}$; Ha $=6.4 \mathrm{~mm}$; $\mathrm{Wa}=6.3 \mathrm{~mm} ; \mathrm{Hp}=2.9 \mathrm{~mm} ; \mathrm{Wp}=2.8 \mathrm{~mm}$.

Description: Shell is medium to large, solid, moderately curved, narrow and elongated, open at both ends. Dorsal side is concave, and the ventral is convex. The apex is damaged in all the collected specimens. The shell narrows and slightly curves to the wider anterior opening. The shell is ornamented with solid radial ribs and growth lines. Sharp and moderately high, 8 to 10 radial ribs are near the apical area. Ribs become lower and almost flat near the wider end of the shell. Secondary ribs are inserted 


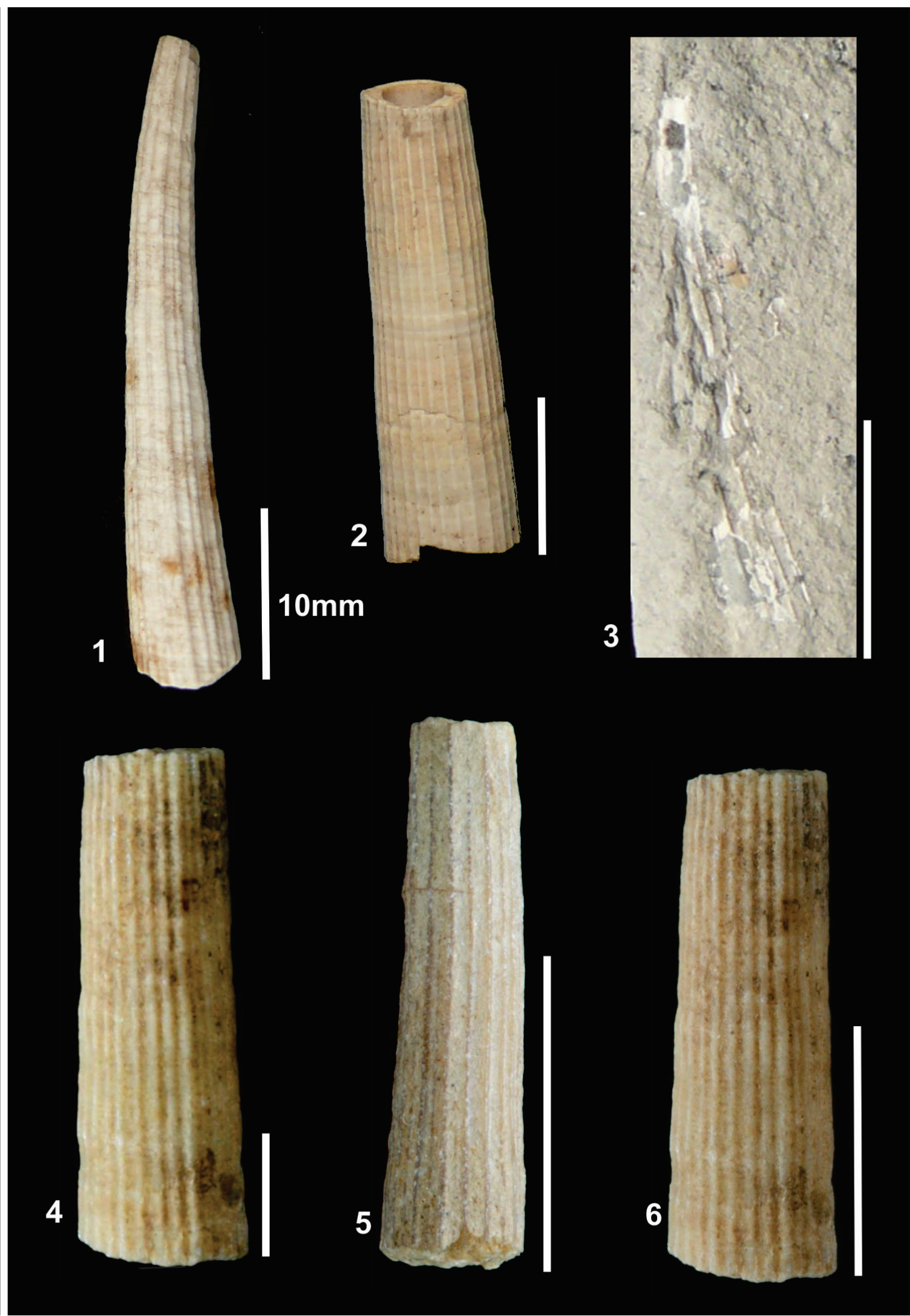

Plate 1. Fissidentalium badense (PARTSCH in HÖRNES, 1856).

1 Višnjica locality, Serbia (Inv. No. K-2347/1);

2 Loznica, Serbia (Inv. No. K-2689);

3 Bogutovo Selo, Bosnia and Herzegovina (Inv. No. K-6746);

4 Čučerje, Croatia (Inv. No. 573);

5 Vrhovčak („Zaprešić Breg“), Croatia (Inv. No. 1.413);

6 Glinsko Pokuplje area, Croatia (Inv. No. 1.220). 
between the primary ribs at various distances from the apex. The maximum number of inserted ribs near the posterior part of the shell does not exceed 30 . The primary and secondary ribs at the posterior side of the shell are almost indistinguishable from each other with only minor differences. The species varies in number and thickness of the secondary ribs. Concave interrib spaces vary in width. Together with the radial ribs, fine and dense irregular growth lines (except in the apical area) characterize the shell surface. The cross-section of both ends is subcircular.

Remarks: Many authors studied the phylogeny and classification of the scaphopods (e.g. REYNOLDS, 1997; REYNOLDS \& AKOKO, 1999). Fissidentalium badense (PARTSCH in HÖRNES, 1856) was first recognized as Dentalium badense (HÖRNES, 1856), Entalis (SACCO, 1897) or Dentalium (Entalis) badensis (KOJUMDGIEVA \& STRACHIMIROV, 1960). F. badense from the Višnjica locality, and presented here, fits the descriptions by PAVIA (1991). The species described in KOJUMDGIEVA \& STRACHIMIROV (1960) has more secondary ribs (35), as do several specimens from Koritnica, Poland (BALLUK, 1972). STEINER \& KABAT (2004) single out the subgenus Dentalium LINNAEUS 1758. In the research of the taxonomy and ecology of the recent genus Fissidentalium (FISCHER), LAMPRELL \& HEALY (1998) indicate the significance of the aperture, and the number and rib morphology that can contribute to the research of the fossil species.

Geographic and stratigraphic distribution: Fissidentalium badense (PARTSCH in HÖRNES, 1856) appears during the Burdigalian in the Mediterranean at the Torino Hills (SACCO, 1897), and in the Lower Miocene of the Paratethys (HARZHAUSER, 2002; HARZHAUSER et al., 2011). F. badense has a wide geographic distribution, and represents a species typical of the Middle Miocene of the Paratethys (e.g. KOJUMDGIEVA \& STRACHIMIROV, 1960; PAVIA, 1991; HARZHAUSER et al., 2011).

\section{DISCUSSION}

In the Badenian sediments of the south and southwestern margin of the Central Paratethys, the majority of scaphopod discoveries belong to the dentaliids. Here, we analyzed and revised Fissidentalium badense (PARTSCH in HÖRNES, 1856) specimens stored at the NHMB and CNHM. Given the number of the recorded dentaliids, Višnjica near Belgrade (Serbia) is the site yielding the largest number of specimens.

At the Višnjica locality, scaphopods were discovered in the clayey sediments, known as the „Višnjica clays“ or the „clays with Pleurothoma". This site was compared to the Badenian stratotype Baden-Sooss in Vienna (PAVLOVIĆ, 1903; LUKOVIĆ, 1922), which contains many specimens of $F$. badense. The stratigraphic position of the „Višnjica clays“ is not precisely determined. Based upon foraminifera, STEVANOVIĆ (1977) attributes it to the Middle Badenian, and GRUJIČIĆ (2010) specifies the zone with Spirorutilus carinatus (d'ORBIGNY). Sandstones containing rare fine-shelled pectens (Costelamussium sp.), Aequipecten macrotis (SOWERBY) and Aequipecten scabrella (LAMARCK) (LUKOVIĆ, 1922) cover the clay stratum. These pectinid species also occur in the Lower Badenian of Bukovac on the Fruška gora Mt. (JOVANOVIĆ, 2014), in the Grund Gaindorf formation in Austria (MANDIC \& HARZHAUSER, 2003; MANDIC, 2004), and in the Lower Badenian (Lagenidae zone) sediments of Szokoly, Hungary (BALDI, 1960). The „Višnjica clays“ contain numerous scaphopod specimens: Fissidentalium badense (PARTSCH in HÖRNES), Gadilina jani HÖRNES, Dentalium sexangulum GMELIN, Dentalium (Antale) novemcostatum decemcostulata
SACCO, Dentalium (Dentalium) michelottii HÖRNES and Fissidentalium mutabile (DODERLEIN).

In the Lower Badenian argillaceous marls of the wider Belgrade region, deep sea molluscs are very common: Neopycnodonte cochlear POLI, Lentipecten corneus denudatus (REUSS), Vaginella austriaca KITTL and Aturia aturi (BASTEROT) (PETKOVIĆ et al., 1976; JOVANOVIĆ, 2014). These findings, as well as the record of Parvamussium duodecimlamellatum (BRONN), indicate a Lower Badenian age (STUDENCKA et al., 1998; SELMECZI et al., 2012; JOVANOVIĆ, 2014). In the Miocene (probably Lower Badenian) marls of the wider Zagreb region („Cučerje“ development on the Medvednica Mt.), the wider Belgrade region and Ugljevik (Bogutovo Selo), together with dentaliids, scaphopods are accompanied by a pelagic fauna of nautilids (Aturia aturi (BASTEROT), pteropods (Vaginella austriaca KITTL) and planktonic foraminifers (KOCHANSKY, 1944; STEVANOVIĆ, 1977, AVANIĆ et al., 1995; JOVANOVIĆ, 2014). These known data, together with further detailed dentaliid analysis, can contribute to the reconstruction of the first Middle Miocene marine transgression in the south and southwestern margin of the Central Paratethys.

All the published data and records suggest that $F$. badense mostly lived in muddy and muddy-sandy substrate at all the studied localities in Serbia, Bosnia and Herzegovina and Croatia. This species was widespread during the Lower Badenian, with fossil evidence from the clayey sediments of Austria (Baden-Sooss) (RÖGL et al., 2009), Romania (Lăpugiu de Sus) (TITA, 2007), Slovakia (BALLUK, 1972; HARZHAUSER et al., 2011), Hungary (BALDI, 1960) and Bulgaria (KOJUMDGIEVA \& STRACHIMIROV, 1960). The distribution of $F$. badense indicates the contemporary marine connections and migration routes. Due to the recorded and afore-mentioned findings, possible migration routes of $F$. badense to the area of Paratethys could be the southwestern („Transtethyan corridor“) and the northern marine passages (e.g. RÖGL, 1998; STUDENCKA et al., 1998; KOVÁČ et al., 2007).

\section{CONCLUSIONS}

This paper presents the scaphopod species Fissidentalium badense (PARTSCH in HÖRNES, 1856) housed at the Natural History Museum Belgrade and the Croatian Natural History Museum. Fossil material was collected from the Badenian (Middle Miocene) deposits of the south and southwestern margin of the Central Paratethys.

The age of the analyzed specimens from Serbia and Bosnia and Herzegovina stored at the Natural History Museum Belgrade is the Lower Badenian, while other Middle Miocene findings are questionable in age and require further research.

During the upper part of the Lower Badenian, the species had a wide geographic distribution, which implys an open marine connection of the Central Paratethys with other marine areas.

According to the available fossil record, Fissidentalium badense lived on a muddy to muddy-sandy substrate.

\section{ACKNOWLEDGMENT}

The authors thank Prof. Sejfudin VRABAC (Faculty of Mining, Geology and Civil Engineering, University of Tuzla, Bosnia and Herzegovina), Prof. Jasenka SREMAC (Faculty of Science, University of Zagreb, Croatia), Dr. Davor VRSALJKO (Croatian Natural History Museum, Zagreb) and anonymous reviewers for useful comments which helped us to improve the paper, and to Dr. Davorka RADOVČIĆ (Croatian Natural History Museum, Zagreb) for help in translating the manuscript. 


\section{REFERENCES}

ANĐELKOVIĆ, M., EREMIJA, M., PAVLOVIĆ, M., ANĐELKOVIĆ, J. \& MITROVIĆ-PETROVIĆ, J. (1991): Badenski vek.-In: ANĐELKOVIĆ, M. (ed.): Paleogeografija Srbije, Tercijar. Univerzitet u Beogradu, Rudarsko-geološki fakultet, Institut za Regionalnu geologiju i paleontologiju Beograd, 134-159.

AVANIĆ, R., PAVELIĆ, D., BRKIĆ, M., MIKNIĆ, M. \& ŠIMUNIĆ, A. (1995): Lapori i biokalkareniti Vejalnice.- In: ŠIKIĆ, K. (ed.): Geološki vodič Medvednice. Institut za geološka istraživanja INA-Industrija nafte, d.d., Zagreb, 159-164.

BAJRAKTAREVIĆ, Z. (1978): Gornjotortonska starost sedimenata Zaprešić-brijega kod Samobora [Upper Tortonian sediments of Zaprešić-Brijeg near Samobor, north Croatia - in Croatian and English].- Geol. vjesnik, 30/1, 63-69.

BAKRAČ, K., HAJEK-TADESSE, V., MIKNIĆ, M., GRIZELJ, A., HEĆIMOVIĆ, I. \& KOVAČIĆ, M. (2010): Evidence for Badenian local sea level changes in the proximal area of the North Croatian Basin.- Geologia Croatica, 63/3, 259-269. doi: $10.4154 / \mathrm{GC} .2010 .21$

BALDI, T. (1960): Tortonische Molluskenfauna von „Badener Tegel-fazies” aus Szokolya, Nordungarn.- Annales historico-naturales Musei nationalis hungarici, $52,51-99$.

BALLUK, W. (1972): Lower Tortonian scaphopods from the Korgtnica clays, southern slopes of the Holy Cross Mts.- Acta Geologica Polonica, 22/3, 545-583.

BASCH, O. (1983a): Osnovna geološka karta SFRJ 1:100000. Tumač za list Ivanić-Grad L 33-81 [Basic Geological Map of SFRY 1:100000, Geology of the Ivanić-Grad sheet - in Croatian].- Geološki zavod, Zagreb (1980), Savezni geološki zavod, Beograd, $81 \mathrm{p}$.

BASCH, O. (1983b): Osnovna geološka karta SFRJ 1:100000. List Ivanić-Grad L 33-81 [Basic Geological Map of SFRY 1:100000, Geology of the Ivanić-Grad sheet].Geološki zavod, Zagreb (1980), Savezni geološki zavod, Beograd.

ĆORIĆ, S., PAVELIĆ, D., RÖGL, F., MANDIC, O., VRABAC, S., AVANIĆ, R., JERKOVIĆ, L. \& VRANJKOVIĆ, A. (2009): Revised Middle Miocene datum for initial marine flooding of North Croatian Basins (Pannonian Basin System, Central Paratethys).- Geologia Croatica, 62/1, 31-43. doi: 10.4154/GC.2009.03

GRUJIČIĆ, LJ. (2010): Foraminifers of the genus Frondicularia from Belgrade area Danubian meander.- In: BANJAC, N., MARAN, A., SAVIĆ, LJ., CUKAVAC, M. \& GANIĆ, M. (eds.): Proceedings of the $15^{\text {th }}$ Congress of Geologists of Serbia with international participation, Belgrade, May 26-29 2010, Serbian Geological Society, 69-72.

HABDIJA, I., PRIMC-HABDIJA, B., RADANOVIĆ, I., ŠPOLJAR, M., MATONIČKIN KEPČIJA, R., VUJČIĆ KARLO, S., MILIŠA, M., OSTOJIĆ, A. \& SERTIĆ PERIĆ, M. (2011): Protista-Protozoa i Metazoa-Invertebrata: Strukture i funkcije. - Alfa d.d., Zagreb, 584 p.

HARZHAUSER, M. (2002): Scaphopoda aus dem Karpatium (Untermiözan) des Korneuburger Beckens (Niederösterreich).- Beitr. Paläont., 27, 205-213.

HARZHAUSER, M., MANDIC, O. \& SCHLÖGL, J. (2011): A late Burdigalian bathyal mollusc fauna from the Vienna Basin (Slovakia).- Geologica Carpathica, 62/3, 211-231. doi: 10.2478/v10096-011-0018-7

HÖRNES, M. (1856): Die fossilen Mollusken des Tertiär-Beckens von Wien. I. Univalven.-Abh. K. K. Geol. Reichsanstalt, 3, 733 p.

JOVANOVIĆ, G. \& JOVANOVIĆ, J. (1998): Tertiary scaphopods in Natural History Museum Belgrade.- Bulletin of the Natural History Museum, A, 47-50, 199-204.

JOVANOVIĆ, G. (2014): Badenske školjke jugoistočnog oboda Panonskog basena (Centralni Paratetis) [Badenian bivalves of the southeastern fringe of Pannonian basin (Central Paratethys) - in Serbian].- Unpubl. PhD Thesis, Faculty of Mining and Geology, University of Belgrade, $252 \mathrm{p}$.

KAUTSKY, F. (1925): Das Miocän von Hemmoor und Basbeck-Osten.- Abhandl. Preuss. Geol. Landesanst. (NF), 97, 1-225.

KNUDSEN, J. (1964): Scaphopoda and Gastropoda from depths exceeding $6000 \mathrm{~m} .-$ Galathea Reports, 7, 125-136.

KOCHANSKY, V. (1944): Fauna marinskog miocena južnog pobočja Medvednice (Zagrebačke gore) [Miozäne marine Fauna des südlichen Abhanges der Medvednica - Zagreber Gebirge - in Croatian and German].- Vjestnik Hrv. drž. geol. zav. i Hrv. drž. geol. muz., 2-3, 171-280.

KOCHANSKY-DEVIDÉ, V. (1957): O fauni marinskog miocena i o tortonskom, „šliru” Medvednice (Zagrebačka Gora) [Ueber die Fauna des marinen Miozäns und über den Tortonischen "Schlier" von Medvednica (Zagreber Gebirge) - in Croatian and German].- Geol. vjesnik, 10 (1956), 39-50.

KOJUMDGIEVA, E. \& STRACHIMIROV, B. (1960): Le Tortonien du type viennois (in Bulgarian with French summary).- In: KOJUMDGIEVA, E. \& STRACHIMIROV, B. (eds.): Les fossilles de Bulgarie, VII, Tortonien.-Académie des Sciences de Bulgarie, Sofia, $246 \mathrm{p}$.

KOVÁČ, M., ANDREYEVA-GRIGOROVICH, A., BAJRAKTAREVIĆ, Z., BRZOBOHATÝ, R., FILIPESCU, S., FODOR, L., HARZHAUSER, M., NAGYMAROSY, A., OSZCZYPKO, N., PAVELIĆ, D., RÖGL, F., SAFTIĆ, B., SLIVA, L. \& STUDENCKA, B. (2007): Badenian evolution of the Central Paratethys Sea: paleogeography, climate and eustatic sea-level changes.- Geologica Carpathica, $58,6,579-606$.
LAMPRELL, K.L. \& HEALY, J.M. (1998): A revision of the Scaphopoda from Australian waters (Mollusca).- Records of the Australian Museum, Supplement 24, 1-189.

LUKOVIĆ, M. (1922): Facije drugog mediteranskog kata u okolini Beograda.-Geološki anali Balkanskoga poluostrva, 7/1, 22-41.

MANDIC, O. (2004): Pectinid bivalves from the Grund Formation (Lower Badenian, Middle Miocene, Alpine-Carpathian Foredeep) - taxonomic revision and stratigraphic significance.- Geologica Carpathica, 55, 129-146.

MANDIC, O. \& HARZHAUSER, M. (2003): Molluscs from the Badenian (Middle Miocene) of the Gaindorf Formation (Alpine Molasse Basin, NE Austria) - Taxonomy, Paleoecology and Biostratigraphy.-Annalen des Naturhistorischen Museums in Wien, $104 \mathrm{~A}, 85-12$.

PAVELIĆ, D. (2001): Tectonostratigraphic model for the North Croatian and North Bosnian sector of the Miocene Pannonian Basin System.- Basin Research, 12, 359 376. doi: 10.1046/j.0950-091x.2001.00155.x

PAVELIĆ, D. (2002): The South-Western Boundary of Central Paratethys.- Geologica Croatica, 55/1, 83-92.

PAVIA, G. (1991): I molluschi del Messiniano di Borelli (Torino). 2. Scaphopoda.- Boll. Mus. Reg. Sci. Nat. Torino, 9/1, 105-172.

PAVLOVIĆ, P. (1903): Prinove Geološkog Zavoda Velike Škole.- Geološki anali Balkanskoga poluostrva, 6, 294-325.

PAVLOVSKY, M. (1957): Prilog poznavanju miocenskih gastropoda Zaprešić-brijega kraj Samobora [Ein Beitrag zur Kenntnis miozäner Gastropoden von Zaprešićbrijeg bei Samobor - in Croatian and German].- Geol. vjesnik, 10, 51-55.

PAVLOVSKY, M. (1960): Novi elementi faune Zaprešić-brijega kraj Samobora [Neue Elemente der Fauna von Zaprešić-brijeg bei Samobor - in Croatian and German].Geol. vjesnik, 13, 213-216.

PETKOVIĆ, K., ČIČULIĆ-TRIFUNOVIĆ, M., PAŠIĆ, M. \& RAKIĆ, M. (1976): Fruška Gora-monografski prikaz geološke građe i tektonskog sklopa.- Matica srpska. Odeljenje za prirodne nauke Novi Sad, 277 p.

PETROVIĆ, M. (1967): Prilog poznavanju tortonskih foraminifera iz Beograda i bliže okoline.- Geološki anali Balkanskoga poluostrva, 29, 27-38.

PEZELJ, Đ., MANDIC, O. \& ĆORIĆ, S. (2013): Paleoenvironmental dynamics in the southern Pannonian Basin during initial Middle Miocene marine flooding.Geologica Carpathica, 64/1, 81-100.

PIKIJA, M. (2009): Litavac i klastične naslage s vulkanitima (baden - M4).- In: VELIĆ, I. \& VLAHOVIĆ, I. (eds.): Tumač Geološke karte Republike Hrvatske 1:300.000 [Geological Map of the Republic of Croatia].- Hrvatski geološki institut, Zagreb, $86-87$.

PILAR, GJ. (1873): Trećegorje i podloga mu u Glinskom Pokuplju.- Rad Jugosl. akad. znan. umjet., 25, 53-179.

PILLER, W.E., HARZHAUSER, M. \& MANDIC, O. (2007): Miocene Central Paratethys stratigraphy - current status and future directions.- Stratigraphy, 4, 2/3, 151168.

REYNOLDS, P. (1997): The phylogeny and classification of Scaphopoda (Mollusca): an assessment of curent resolution and cladistic reanalysis.- Zoologica Scripta, 26/1, doi: 13-21. 10.1111/j.1463-6409.1997.tb00406.x

REYNOLDS, P. \& AKIKO, O. (1999): Phylogenetic relationships among families of the Scaphopoda (Mollusca).- Zoological Journal of the Linnean Society, 126, 131-154. doi: 10.1111/j.1096-3642.1999.tb00151.x

RÖGL, F. (1998): Palaeogeographic Considerations for Mediterranean and Paratethys Seaways (Oligocene to Miocene).- Annalen des Naturhistorischen Museums in Wien, 99 A, 279-310, Wien.

RÖGL, F. (1999): Mediterranean and Paratethys. Facts and Hypotheses of an Oligocene to Miocene Paleogeography (Short overview).- Geologica Carpathica, 50/4, 339-349.

RÖGL, F., ĆORIĆ, S., HARZHAUSER, M., JIMENEZ-MORENO, G., KROH, A., SCHULTZ, O., WESSELY, G. \& ZORN, I. (2009): Biostratigraphy of the Middle Miocene stratotype at Baden-Sooss (Lower Austria).- In: FILIPESCU, F. (ed.): $3^{\text {rd }}$ International Workshop: Neogene of Central and South-Eastern Europe Cluj-Napoca, May 20-24, Abstract Volume, 87-88.

ROUTNEROVÁ, K. (2013): Nové nálezy badenských měkkýšů z lokality Lapugiu de Sus (Rumunsko) [New finds of Badenian molluscs from Lapugiu de Sus (Romania) - in Romanian, with an English Abstract].- Unpubl. Thesis, Faculty of Science, Masaryk University, $30 \mathrm{p}$.

SACCO (1897): I molluschi dei terreni terziarii del Piemonte e della Liguria. Parte XXII, Torino, $148 \mathrm{p}$.

SAVIĆ, LJ., KRSTIĆ, N., TROFIMOVIĆ, N., JEČMENICA, Z. \& JOVANOVIĆ, G. (2005): Badenske lagune Ugljevika [Badenian lagoons of Ugljevik - in Serbian, with an English Summary].- Zapisnici Srpskog Geološkog Društva za 1998-2003, 25-33.

SELMECZI, I., LANTOS M., BOHN-HAVAS, M., NAGYMAROSY, A. \& SZEGÖ, E. (2012): Correlation of bio- and magnetostratigraphy of Badenian sequences from western and northern Hungary.- Geologica Carpathica, 63/3, 219-232. doi: 10.2478/v10096-012-0019-1 
SILVA-FILHO, G.F.S., TENÓRIO, D.O., PINTO, S.L. \& ALVES, M.S. (2012): Mollusca Scaphopoda Bronn, 1862 da Costa Nordeste do Brasil.- Tropical Oceanography, 40/1, 29-103.

STEINER, G. (1999): A new genus and species of the family Annulidentaliidae (Scaphopoda: Dentalida) and its systematic implications.- Journal of Molluscan Studies, $65 / 2,151-161$

STEINER, G. \& KABAT, A.R. (2001): Catalog of superspecific taxa of Scaphopoda (Mollusca).- Zoosystema, 23/3, 433-460.

STEINER, G. \& KABAT, A.R. (2004): Catalog of species-group names of recent and fossil Scaphopoda (Mollusca).- Zoosystema, 26/4, 549-726.

STEVANOVIĆ, P. (1949): Prilozi za stratigrafiju miocenskih naslaga u basenu Korenite - Jadra (Podrinje).- Glasnik Prirodnjačkog muzeja u Beogradu, 9, 1-50.

STEVANOVIĆ, P. (1977): Miocen okoline Beograda.- In: PETKOVIĆ, K. (ed.): Geologija Srbije (Stratigrafija Kenozoika) 2 (3). Zavod Regionalnu geologiju i paleontologiju Rudarsko-geološkog fakulteta Univerziteta u Beogradu, Beograd, $107-145$.

STUDENCKA, B., GONTSHAROVA, I. A. \& POPOV, S.V. (1998): The bivalve faunas as a basis for reconstruction of the Middle Miocene history of the Paratethys.-Acta Geologica Polonica, 48/3, 285-342.

ŠIKIĆ, K., BASCH, O. \& ŠIMUNIĆ, A. (1978): Osnovna geološka karta SFRJ 1:100000, list Zagreb L33-80 [Basic Geological Map of SFRY 1:100000, Zagreb sheet - in Croatian].- Institut za geološka istraživanja Zagreb (1972), Savezni geološki zavod, Beograd.

ŠIKIĆ, K., BASCH, O. \& ŠIMUNIĆ, A. (1979): Osnovna geološka karta SFRJ 1:100000. Tumač za list Zagreb L33-80 [Basic Geological Map of SFRY 1:100000, Geology of the Zagreb sheet - in Croatian].- Institut za geološka istraživanja Zagreb (1972), Savezni geološki zavod, Beograd, $81 \mathrm{p}$.
ŠUKLJE, F. (1929): Mediteranska fauna Zaprešić-brijega u Samoborskoj gori [Mediterranean fauna in Zaprešić Brijeg location in the Samoborska gora Mt. - in Croatian].- Vijesti geološkog zavoda, 3, 1-52.

TAUBER. A. F. (1947): Lebensspuren von Krebsen an fossllen Scaphopodenschalen.In: PAPP, A., ZAPFE, H., BACHMAYER, F. \& TAUBER, A.F.: Lebensspuren mariner Krebse. S. B. Akad. Wiss. Wien, Abt. 1, Bd. 155.

TITA, R. (2007): Comments on the Badenian fauna (Middle Miocene) from Bahna (Southern Carpathians, Romania).- Travaux du Museum national d'Histoire Naturelle Grigore Antipa, 50, 543-554.

VRABAC, S. \& MIHAJLOVIĆ, Đ. (1990): Paleontološko-biostratigrafske odlike i odnos badena i sarmata na površinskom kopu Bogutovo Selo kod Ugljevika (SI Bosna) [Paleontological-biostratigraphical character and relationship of Badenian and Sarmatian at open-pit mine Bogutovo Selo near Ugljevik (NE Bosnia) in Bosnian/Serbian/Croatian].- XII kongres geologa Jugoslavije, Ohrid, knj. I, 312-328.

VRABAC, S., ĆORIĆ, S., ĐULOVIĆ, I. \& JEČMENICA, Z. (2013): Biostratigrafske zone donjeg badena u profilu bušotine Ui - 568/3 kod Ugljevika.- In: BABAJIĆ, E., ĐURIĆ, N., HRVATOVIĆ, H. \& SKOPLJAK, F. (eds.): Zbornik radova V savjetovanja geologa Bosne i Hercegovine sa međunarodnim učešćem, Pale, 136-145.

VRABAC, S., ĐULOVIĆ, I. \& JEČMENICA, Z. (2014): Baden i sarmat u profilu KR -5 kod Ugljevika.- Glasnik Rudarsko-geološko-građevinskog fakulteta, 2, 39-50.

VRSALJKO, D. (2003): Biostratigrafija miocenskih naslaga Žumberačkog i Samoborskog gorja na temelju mekušaca [Biostratigraphy of the Miocene deposits from the Žumberak Mt. and Samoborsko gorje Mts. on the basis of molluscs - in Croatian, with an English abstract].- Unpubl. PhD Thesis, University of Zagreb, $143 \mathrm{p}$

ŽUJOVIĆ, J. (1889): Osnovi za geologiju Kraljevine Srbije sa skicom geološke gradje.Geološki anali Balkanskoga poluostrva, 1, 1-130. 